EESTI NSV TEADUSTE AKADEEMIA TOIMETISED 1955. IV kd., nr. 3 ИЗВЕСТИЯ АҚАДЕМИИ НАУК ЭСТОНСКОИ ССР 1955. ТОМ IV, N 3

\title{
MULLA KIVISUSE UURIMISE METOODIKAST JA UURIMISTULEMUSTEST EESTI NSV-S
}

\section{K. KILDEMA}

Eesti NSV muldadel, mis enamasti sisaldavad ohtralt kive, osutub kivide koristamine üheks tähtsamaks põllutööde täielikuma mehhaniseerimise, kõrge agrotehnika rakendamise ja saakide tõstmise eeltingimuseks.

Et õigesti hinnata kivide koristamise tähtsust, on vaja teada, missugune ja kui suur on kivide koristamisest saadav kasu.

Põldude kivisus takistab põllutööde edukat teostamist mitmeti.

E s it e ks raskendab see mehhaniseerimist masinate ja riistade osade ning sõlmede purunemise ja deformatsiooni tõttu. Puhtast tööajast kulub kivide ületamiseks künnil $25-40 \%$ *, mulla kivisuse tõttu purunenud osade remondiks aga kulub $30-50 \%$ kogu tööajast, mistõttu töid ei teostata ettenähtud tähtaegadeks. Peale selle tõuseb tunduvalt kütusekulu ja ülenormatiivsetest remondikuludest läheb traktorijaamades peaaegu $1 / 3$ kividest tingitud avariide likvideerimiseks (Järva-Jaani jt. traktorijaamade andmeil).

T e is e ks halveneb harimis-, külvi- ja koristustööde kvaliteet (kus kivide all on $3-5 \%$ pinnast, on ligikaudu $15-20 \%$ mast halvasti haritud ja madala saagiga). Kivisus takistab ka eesrindliku agrotehnika (ruutpesiti istutamine, reavahelt harimine, sügavkünd, sügavkobestus, Maltsevi süsteem·jt.) kasutuselevõttu.

Kol m a n d a ks läheb 3-15\% kasulikku põllupinda kaotsi ja hakkab levima umbrohi, mis on tingitud harimata maatükkidest kivide ja kivivarede ümber.

$\mathrm{Ne} l \mathrm{j}$ a n d a ks väheneb mulla viljakus, mis on tingitud kiviste muldade halvematest füüsikalistest omadustest $(1,2)$, maaharimise madalast kvaliteedist ning kogu agrotehniliste vôtete kompleksi väiksemast efektiivsusest. Praktika näitab, et pärast kivide koristamist tõuseb põllumajanduslike kultuuride saak. Uksikutel juhtudel on see tõus ulatunud $100 \%$-ni.

Kui kivisusest tingitud kahjud kokku arvata, liita nendele kivide kui ehitusmaterjali hind ** ning tulemusest lahutada kivide koristamise maksumus $\left(5-15 \mathrm{rbl} .1 \mathrm{~m}^{3}\right)$, siis võime olemasolevate andmete pöhjal julgesti öelda, et kivide koristamine on majanduslikult väga kasulik ja suure riikliku tähtsusega maaparandusabinõu.

Eesti NSV territooriumil on esialgsete andmete põhjal põllumajandus-

* Eesti NSV Teaduste Akadeemia Taimekasvatuse Instituudi teadusliku töötaja V. Kosari andmeil.

** 1 ruumimeeter kive maksab ladustamiskohas $17 \mathrm{rbl}$., ehitusplatsil $51 \mathrm{rbl}$., tihumeetri hind on $30 \div 50 \%$ kallim. 
like maade kivide üldhulka maapinnal ja künnikihis hinnatud kuni 30 miljoni kuupmeetrini. Kividest puhastamist vajab $60 \%$ põllumajandusliku maa üldpinnast. Neil maadel on künnikihis tavaliselt 50-1000 $(20-120 \mathrm{~cm}$ läbimõõduga) kivi 1 hektaril, üksikutes kohtades aga ulatub see arv kahe tuhandeni ja üle selle.

Eesti NSV-s teostatakse suureulatuslikke kivide koristamise töid, näiteks 1953. aastal koristati traktorijaamade poolt pōldudelt $600000 \mathrm{~m}^{3}$ kive* (mis vastab ligikaudu 30000 ha-le). See on 4 korda rohkem kui 1950. aastal. Kuid nende tööde organisatsiooniline tase ja kvaliteet on veel ebarahuldav $\left({ }^{8}\right)$.

Kahjuks on mulla kivisuse uurimisele pööratud seni vähe tähelepanu. Küllalt tõsist allakriipsutamist on see küsimus leidnud ainult ühes raamatus $\left({ }^{2}\right)$. Mõningaid andmeid muldade kivisuse kohta leiame kvaternaargeoloogia, geomorfoloogia ja geograafia alastes töödes ning vähesel määral ka pinnaseteaduslikes väljaannetes.

Käesolev töö on kirjutatud väliuurimiste põhjal, mis teostati 1953. ja 1954. aasta suvel Eesti NSV Teaduste Akadeemia Taimekasvatuse Instituudi poolt. Uurimistöid teostati 1953. aastal põllumajandustehnikumide õpilaste kaasabil; 1954. aasta suvel võtsid uurimistöödest osa Tartu Riikliku Ulikooli geograafia osakonna üliõpilased $M$. Kippasto ja V. Lepasepp.

Kivisuse uurimise ülesanded on järgmised:

1. Põllumajanduse praktika huvidele vastava metoodika väljatöötamine kivide hulga ja kubatuuri määramiseks.

2. Kivisuse leviku, iseloomu, rajooniliste erinevuste ja kivide mullas paiknemise seaduspärasuste selgitamine.

3. Kivisuse ülevaatekaardi koostamine, mis võimaldaks

a) kivikoristustöid planeẹrida;

b) ära määrata suure kivisusega piirkonnad, kus on vaja teha muudatusi kasvatatavate kultuuride valikus, agrotehnikas ja maakasutuses kõlvikute ratsionaalsema kasutamise eesmärgil;

c) masina-traktorijaamade ja sovhooside töönorme diferentseerida kivisuse suhtes ning teostada masinate õiget suunamist (rajoonimist).

4. Kivide koristamise agraar-ökonoomilise efekti väljaselgitamine, et neid andmeid kasutada agropropagandas ja kõlvikute parandamise ja transformeerimise projektide koostamisel.

5. Andmete kogumine kiviste muldade füüsikalis-mehaaniliste omaduste kohta, et selgitada nende omaduste mõju mulla arengule ja viljakusele.

\section{MULLA KIVISUSE UURIMISE METOODIKA}

Autori poolt kasutusele võetud uurimismetoodika põhiprintsiipideks on: a) komplekssus, s. t. ajaloolis-looduslike tingimuste ja põllumajandusliku tootmise erinevuste seostatud arvestamine; b) marsruut-, rekognoos- ja detailuurimise kombineeritud kasutamine sõltuvalt füüsilis-geograafiliste tingimuste ja tootmistingimuste (kivisuse aste, kiviste põldude pindala suhe põllumaa kogusuurusega, mulla viljakus jne.) erinevustest.

1. Kivide suuruse ja kubatuuri määramine omab väga suurt tähtsust mulla kivisuse uurimisel, kivide koristamisel (töönormide määramisel ja koristatud kivide mahu arvestamisel), mitmesugustel ehitustöödel jne. Taimekasvatuse Instituudis on välja töötatud esialgne kivide suuruse ja kubatuuri määramise metoodika, kus kivi suuruse määramise aluseks on võetud kivi maksimaalne diameeter.

Umara kujuga kivide (millede maksimaalne diameeter on $20-300 \mathrm{~cm}$ )

* Eesti NSV Pōllumajanduse Ministeeriumi andmeil. 
kubatuuri määramiseks on koostatud vastav tabel (vt. tabel 1). Kivi kubatuur määratakse tabelist ühe mõõtme põhjal, s. t. maksimaalse diameetri järgi. Arvestuste aluseks kivide kubatuuride määramisel võeti kolmetelje. line ellipsoid kui keha, millele kivide tegelik kuju on kõige lähedasem ja paremini taandatav. Tabeli koostamiseks mõõdeti looduses eri rajoonides üle 700 kivi, leiti telgede keskmised suhted $\left(\frac{a}{b}\right.$ ja $\left.\frac{c}{a}\right)$ fraktsioonide kaupa ja arvutati maksimaalsetele diameetritele vastavad kubatuurid kolmeteljelise ellipsoidi puhul.

Tabeli järgi on lubatav arvestada 10 ja suurema arvu kivide kogumahtu, sest üksikute kivide puhul võib viga kujuneda lubamatult suureks. Arves-

Kivide ligikaudne maht kuupdetsimeetrites

Tabel 1

\begin{tabular}{|c|c|c|c|c|c|c|c|c|c|}
\hline \multirow{2}{*}{$\begin{array}{l}\text { Kivi maksi- } \\
\text { maalne labi- } \\
\text { mőరt cm }\end{array}$} & \multicolumn{9}{|c|}{ Kivide arv } \\
\hline & 1 & 2 & 3 & 4 & 5 & 6 & 7 & 8 & 9 \\
\hline 20 & 2 & 4 & 6 & 8 & 10 & 12 & 14 & 16 & 18 \\
\hline 25 & 4 & 8 & 11 & 16 . & 20 & 23 & 27 & 31 & 35 \\
\hline 30 & & 14 & 20 & 27 & 34 & 41 & 47 & 54 & 61 \\
\hline 35 & . 11 & 21 & 32 & 43 & 54 & 64 & 75 & 86 & 96 \\
\hline 40 & 16 & 32 & 48 & 64 & 80 & 96 & 110 & 130 & 150 \\
\hline 45 & 19 & 38 & 57 & 77 & 96 & 110 & 130 & 150 & 170 \\
\hline 50 & 26 & 53 & 79 & 100 & 130 & 160 & 180 & 200 & 240 \\
\hline 55 & 35 & 70 & 100 & 140 & 170 & 210 & 240 & 280 & 310 \\
\hline 60 & 45 & 91 & 140 & 180 & 230 & 270 & 320 & 360 & 410 \\
\hline 65 & 58 & 120 & 170 & 230 & 290 & 350 & 400 & 460 & 520 \\
\hline 70 & 69 & 140 & 210 & 270 & 340 & 410 & 480 & 550 & 620 \\
\hline 75 & 84 & 170 & 250 & 340 & 420 & 510 & 590 & 680 & 760 \\
\hline 80 & 100 & 200 & 310 & 410 & 510 & 610 & 720 & 820 & 920 \\
\hline 85 & 120 & 250 & 370 & 490 & 610 & 740 & 860 & 980 & 1100 \\
\hline 90 & 150 & 290 & 430 & 580 & 730 & 870 & 1000 & 1200 & 1300 \\
\hline 95 & 170 & 340 & 510 & 690 & 860 & 1000 & 1200 & 1400 & 1500 \\
\hline 100 & 180 & 360 & 540 & 720 & 900 & 1100 & 1300 & 1500 & 1600 \\
\hline 105 & 200 & 420 & 630 & 830 & 1000 & 1300 & 1500 & 1700 & 1900 \\
\hline 110 & 240 & 480 & 720 & 960 & 1200 & 1400 & 1700 & 1900 & 2200 \\
\hline 115 & 270 & 550 & 820 & 1100 & 1400 & 1600 & 1900 & 2200 & 2500 \\
\hline 120 & 310 & 620 & 930 & 1200 & 1600 & 1900 & 2200 & 2500 & 2800 \\
\hline 125 & 350 & 700 & 1100 & 1400 & 1800 & 2100 & 2500 & 2800 & 3200 \\
\hline 130 & 400 & 800 & 1200 & 1600 & 2000 & 2400 & 2800 & 3200 & 3600 \\
\hline 135 & 440 & 890 & 1300 & 1800 & 2200 & 2700 & 3000 & 3500 & 4000 \\
\hline 140 & 500 & 1000 & 1500 & 2000 & 2500 & 3000 & 3500 & 4000 & 4500 \\
\hline 145 & 520 & 1000 & 1600 & 2100 & 2600 & 3100 & 3600 & 4000 & 4700 \\
\hline 150 & 540 & 1100 & 1600 & 2200 & 2700 & 3200 & 3800 & 4300 & 4900 \\
\hline 155 & 560 & 1100 & 1700 & 2200 & 2800 & 3300 & 3900 & 4500 & 5000 \\
\hline 160 & 620 & 1200 & 1800 & 2500 & 3000 & 3700 & $43 \cap 0$ & 5000 & 5500 \\
\hline 165 & 670 & 1300 & 2000 & 2700 & 3400 & 4000 & 4700 & 5400 & 6100 \\
\hline 170 & 740 & 1500 & 2200 & 2900 & 3700 & 4400 & 5200 & 5900 & 6600 \\
\hline 175 & 800 & 1600 & 2400 & 3200 & 4000 & 4800 & 5600 & 6400 & 7200 \\
\hline 180 & 880 & 1800 & 2600 & 3500 & & 5300 & 6100 & 7000 & 7900 \\
\hline 185 & 950 & 190 & 2900 & 3800 & 480 & 5700 & 6700 & 7600 & 8600 \\
\hline 190 & 1000 & 2100 & 3100 & 4100 & 510 & 6200 & 7200 & 8200 & 9300 \\
\hline 195 & 1110 & 2200 & 3.30 & 44 & & 670 & 7800 & 8900 & 10000 \\
\hline 200 & 1200 & 2400 & 3600 & 4800 & 600 & 7200 & 8400 & 9600 & 10200 \\
\hline 210 & 1390 & 2800 & 4200 & 5600 & & 830 & 9700 & 11100 & 12500 \\
\hline 220 & 1600 & 320 & & 640 & 80 & 9600 & 11200 & 12300 & 14400 \\
\hline 230 & 1830 & 3700 & 5500 & 7300 & 9100 & 11000 & 12800 & 14600 & 16400 \\
\hline 240 & 2070 & & 620 & 830 & & 1240 & 15500 & $166 \cap 0$ & 18700 \\
\hline 250 & 2340 & 4700 & 7000 & 9400 & 1170 & 14100 & 16400 & 18700 & 21100 \\
\hline 260 & 2640 & 5300 & 7900 & 10500 & 1320 & 15800 & 18500 & 21100 & 23700 \\
\hline 270 & 2950 & 5500 & $89 n 0$ & 11800 & 1480 & 17700 & 20700 & 23600 & 26600 \\
\hline 280 & 3290 & $66 \cap 0$ & 9900 & 13200 & 16500 & 19800 & 23100 & 26300 & 29600 \\
\hline 290 & & 7300 & 11000 & 14600 & 18300 & 22000 & 25600 & 29300 & 32900 \\
\hline 300 & 4050 & 8100 & 12200 & 16200 & 20300 & 24300 & 28400 & 32400 & 36500 \\
\hline
\end{tabular}


Kivide klassifikatsioon

\begin{tabular}{|c|c|c|c|}
\hline \multicolumn{2}{|c|}{ Fraktsioonide grupid } & \multicolumn{2}{|c|}{ Fraktsioonid } \\
\hline nimetus & $\begin{array}{c}\text { maksi- } \\
\text { maalne } \\
\text { diameeter }\end{array}$ & nimetus & $\begin{array}{l}\text { maksi- } \\
\text { maalne } \\
\text { diameeter }\end{array}$ \\
\hline $\begin{array}{ll}\begin{array}{l}\text { Hiidrahnud } \\
\text { kivid) }\end{array} & \text { (tard- } \\
\begin{array}{l}\text { Hiidpangased } \\
\text { kivid) }\end{array} & \text { (pae- } \\
\end{array}$ & $10 \mathrm{~m}$ & & \\
\hline $\begin{array}{l}\text { Rahnud } \\
\text { Pangased }\end{array}$ & $1-10 \mathrm{~m}$ & $\begin{array}{l}\text { Suured } \\
\text { Keskmised }\end{array}$ & $\begin{array}{l}3-10 \mathrm{~m} \\
1,5-3 \mathrm{~m}\end{array}$ \\
\hline & & Väikesed. & $1-1,5 \mathrm{~m}$ \\
\hline \begin{tabular}{l} 
Kivid \\
(kitsamas mōttes) \\
Umarad kivid \\
\multicolumn{1}{c}{ paekivid } \\
,$\quad$ tardkivid \\
(raud- \\
kivid) \\
Paeplaadid
\end{tabular} & $100 \mathrm{~cm}$ & Keskmised & $70-100 \mathrm{~cm}$ \\
\hline & & Väikesed . & $20-40 \mathrm{~cm}$ \\
\hline $\begin{array}{l}\text { Veeris } \\
\text { tardkiviveeris } \\
\text { paekiviveeris } \\
\text { segaveeris }\end{array}$ & $1-20 \mathrm{~cm}$ & $\begin{array}{l}\text { Jäme : } \\
\text { Keskmine }\end{array}$ & $\begin{array}{l}10-20 \mathrm{~cm} \\
5-10 \mathrm{~cm}\end{array}$ \\
\hline Răhk & & Peen . & $1-5 \mathrm{~cm}$ \\
\hline
\end{tabular}

On haruldased ja kuuluvad enamasti looduskaitse alla. $\mathrm{Ei}$ kuulu koristamisele.

Esinevad harva $(\sim 1 \%)^{*}$. Koristatakse põllult erandjuhtudel.

Esineb tunduvalt rohkem kui eelmisi $(\sim 2 \%)$, eriti PõhjaEestis. Kuuluvad koristamisele, see on aga ilma lōhkamistöödeta raskustega seotud.

Esinevad mõõdukalt ( 3$-5^{0} \%$ ), peamiselt Põhja-Eestis. Koristamine mehhanismide abil raskusteta teostatav. Ole 1-meetrise diameetriga kivid ei võimalda pōllutööde mehhaniseerimist (purustavad masinaid ja riistu).

Esinevad sagedasti $(\sim 8 \%)$. 20-100-sentimeetrise diameetriga kivid kahjustavad oluliselt masinaid ja riistu, eriti atru. Kuuluvad koristatavate kivide pōhimassi.

Alia 70-sentimeetrise diameetriga kivid moodustavad rändkivide (tardkivide) selgelt eralduva põhimassi $(\sim 40 \%)$. «Serviti pae» sagedaim esinemissuurus. 40-150-sentimeetrise diameetriga kivid on juurija-kogujaga, samuti trossiga hästi koristatavad.

Tardkive massiliselt $\quad(\sim 40-$ $50 \%$ ). Glatsifluviaalses materjalis esineb mõõdukalt ümaraid paekive. Paeplaate rohkesti. Kivikoristamisel käsitsi laaditavad.

Alla 20-sentimeetrise diameetriga kivid moodustavad rannaklibu ja glatsifluviaalse veerise pôhimassi. Kahjustavad peamiselt külvi- ja koristusmasinaid. Koristamine teises järjekorras, mehhaniseeritud koristamine perspektiivne.

Alla 5-sentimeetrise diameetriga kivid ei kuulu koristamisele.

* Protsendid on antud üle $20 \mathrm{~cm}$ läbimõõduga rändkivide mahulise osatähtsuse kohta; andmed on provisoorsed. 
tades aga seda, et praktikas on tegemist alati suure kivide arvuga, osutub selline mahu määramine otstarbekaks. Tabeli eksperimentaalne kontroll (kivi mahu määramisega ülevooluanumas) andis 50 kivi puhul vea kuni $8 \%$. Seda tabelit, mida juba kasutavad paljud masina-traktorijaamad ja sovhoosid, on võimálik veelgi täpsustada. Uhtlasi on selgunud, et senini ülehinnati kivikoristustöödel koristatud kivide kubatuuri 2-3 korda ja veelgi rohkem, sest määramisi teostati silma järgi. Ka on selgunud, et kivikoristustööde normid ei ole praktiliselt põhjendatud ega vasta tegelikule tööjõudlusele.

Samalaadse tabeli võib välja töötada teravaservaliste paekivide jaoks.

Kivisuse uurimisel on vaja hinnata ka olemasolevate kivikogumike kivihunnikute ja -tarade - kubatuure (kivide varu ning koristatud kivide hulga määramiseks). Kivihunniku maht arvestatakse välja hunnikule kõige rohkem sarnaneva geomeetrilise kujundi ruumala valemi järgi, kusjuures tühikute arvel arvatakse maha $30-50 \%$. Sagedasti on kivihunnik kujult segment yõi risttahukas. Kivitarade puhul tuleb mõõta tara pikkus ja arvutada keskmine jooksva meetri kubatuur.

Kivide kubatuuri määramiseks fraktsioonide järgi on kasutusele võetud tabelis 2 esitatud klassifikatsioon. Tabelis on kivid eraldatud suuruse ja kuju järgi, kusjuures nende eraldamisel võeti arvesse varem välja töötatud klassifikatsioone (Ohhotini $\left({ }^{4}\right)$ jt.), kivide keskmisi suurusi ja muid geneesi iseloomustavaid omadusi, kuid ka praktika huve.

Räha ja veerise hulga määramiseks mullas võib kasutada kaht meetodit katteväärtuse järgi ja viit meetodit mahu järgi.

Katteväärtust määratakse nii horisontaal- kui ka vertikaalpindadel järgmiselt.

1) Spetsiaalse raami $(50 \times 50 \mathrm{~cm})$ abil, mis on varustatud traadist vōi nöörist võrguga (traadid iga $10 \mathrm{~cm}$ järel), kusjuures määramine toimub silmaga 1-ruutmeetriliselt lapilt 5\%-lise täpsusega. Veelgi hõlpsam ja täpsem on määramine $10 \times 10 \mathrm{~cm}$ (või $15 \times 15 \mathrm{~cm}$ ) suuruse resti (traadid $1 \mathrm{~cm}$ järel) kasutamisel, mida seni edasi tõstetakse, kuni soovitud suurusega pinna katteväärtus on määratud.

2) Fotomeetodil, mis seisab selles, et maapinnal tähistatud $0,5-1 \mathrm{~m}^{2}$ suurune ala fotografeeritakse, positiivile tõmmatakse peale ruudustik ja hinnatakse katteväärtus juba foto järgi (joon. 1): Selle meetodi eelisteks on kivide loodusliku esinemispildi täpne fikseerimine ja väiksem ajakulu.

Mõlema meetodi puhul on soovitav võtta vähemalt 3 proovilappi (igaüks $\left.0,5-1 \mathrm{~m}^{2}\right)$ : üks räha (veerise) maksimaalse, teine minimaalse ja kolmas keskmise katteväärtusega kohast.

Selleks, et katteväärtuse järgi saaks otsustada kivide kogumahu üle, tuleb leida vastavad ümberarvestus-koefitsiendid. Et aga selline arvestusviis on võrdlemisi ebatäpne, siis tuleb eelistada räha (veerise) mahu otsest hindamist.

Räha (veerise) mahu otseseks hindamiseks võib kasutada alljärgnevaid viise: 1) kivide eraldamine fraktsioonidesse ja nende mahu määramine loendamise abil fraktsioonide kaupa; 2) kivide ladumine korrapärastesse hunnikutesse (saadud üldmahust tuleb tühikute arvel 40-50\% maha arvata); 3) kivide mahu määramine kuupdetsimeetri või spetsiaalse mõõtkasti abil; 4) kivide kaalumine; 5) kivide mahu määramine veeanumas.

Meie poolt on kasutatud $10-20$-sentimeetrise diameetriga kivide puhul esimest viisi, $1-10$-sentimeetrise diameetriga kivide puhul aga kolmandat ja viiendat viisi. Uurimise tulemusena selgus, et $1-5$-sentimeetrise diameetriga veerise üldmahust on tühikute all keskmiselt $40-45 \%$, rähal aga $45-50 \%$.

Kivisuse astme määramisel võtsime esialgselt kasutusele näitajad, mis esinevad kirjanduses $\left({ }^{2}\right)$, kuid mõningate täiendustega. 


\begin{tabular}{|c|c|c|c|c|}
\hline $\begin{array}{l}\text { Kivisuse } \\
\text { aste }\end{array}$ & $\begin{array}{l}\text { Kivide } \\
\text { hulk } \\
\mathrm{m}^{3} / \mathrm{ha}\end{array}$ & Tähistus & $\begin{array}{c}\text { Orienteeruv } \\
\text { territoriaalne } \\
\text { ulatus }(\%) \\
\text { Eesti NSV-s }\end{array}$ & $M$ ärkusi \\
\hline Väga tugev & Ole 100 & V & 10 & $\begin{array}{l}\text { Kivikoristamist ei teostata. Sobivad } \\
\text { karjamaadeks, metsastamiseks, parki- } \\
\text { deks. } 50 \text {-sentimeetrise diameetriga } \\
\text { kivide arv ha-1 üle } 3200 \text {. }\end{array}$ \\
\hline Tugev & $50-100$ & IV & 35 & $\begin{array}{l}\text { Kivikoristamist künnimaadelt teosta- } \\
\text { takse ainult viljakamate muldade } \\
\text { puhul. Soovitav rajada pealtparanda- } \\
\text { tavateks rohumaadeks ja viia lutserni } \\
\text { alla. } 50 \text {-sentimeetrise diameetriga ki- } \\
\text { vide arv ha- }-1600-3200 \text {. }\end{array}$ \\
\hline Keskmine & $20-50$ & III & 20 & $\begin{array}{l}\text { Kivikcristamine otstarbekohane. } 50 \text {-senti- } \\
\text { meetrise diameetriga kivide arv ha-1 } \\
640-1600 \text {. }\end{array}$ \\
\hline Nõrk . . & $5-20$ & II & 15 & $\begin{array}{l}\text { Kivikoristamine soovitav esmajärjekorras. } \\
50 \text {-sentimeetrise diameetriga kivide arv } \\
\text { ha-1 } 160-640 \text {. }\end{array}$ \\
\hline Väga nōrk & Alla 5 & I & 20 & $\begin{array}{l}\text { Kivikoristamine vajalik, kui põllul on üle } \\
2 \mathrm{~m}^{3} \text { kive, millede diameeter on üle } \\
20 \mathrm{~cm} \text {. 50-sentimeetrise diameetriga } \\
\text { kivide arv ha-l alla } 160 \text {. }\end{array}$ \\
\hline
\end{tabular}

2. Välitööde metoodika. Välitööde põhilisteks koostisosadeks mulla kivisuse selgitamisel on pinnakivisuse uurimine koos kivikogumike arvu ja mahu kindlakstegemisega ja peitkivisuse uurimine (künnikihis ja allpool seda).

Pinnakivisust määratakse mõõtlappidel ja marsruudikorras. Mõõtlapp võetakse tüüpiliselt kohalt, milleks eelnevalt tutvutakse uuritava alaga. Mõõtlapi kujuks on ristkülik, mille pikitelg orienteeritakse pinna kalde suunas. Mõõtlapi suuruseks võetakse sõltuvalt kivisuse astmest ja selle varieeruvusest $500-5000 \mathrm{~m}^{2}$. Mõõtlapil loendatakse kivid fraktsioonide kaupa. Väikeste lappide puhul võib teostada ka takseerimist, s. o. suuruse määramist iga kivi eraldi mõõtmise teel. Marsruutmeetodil määratakse pinnakivide hulk kahel viisil: 1) $100 \mathrm{~m}$ pikkusel ja 5-10 m laiusel ribal loendatakse kivide hulk ja hinnatakse silma järgi nende keskmine diameeter; 2) silmaga hinnatakse pinnakivisuse astet nähtavate kivide ja kivikogumike järgi (see eeldab teatud vilumust).

Väga tähtis on uurida kivisust künnikihis ja allpool seda, sest peitkividest tingitud kahjustused masinatele on suured ja raskemini välditavad.

Peitkivisuse uurimine võib toimuda alljärgnevatel meetoditel: 1) mitmesuguse suurusega kaevete tegemine (suurus pinnal tavaliselt $2 \times 1 \mathrm{~m}$, sügavus $0,5 \mathrm{~m}$ ), milledes määratakse räha ja veerise sisaldus mullas; 2) künni jälgimine (minimaalselt 0,5 ha-1), kusjuures registreeritakse kividest tingitud tõuked (kivide arv), kivide suurus (mõõdetakse vähemalt $20 \%$ kividest), küntud maa pindala suurus ja künni keskmine sügavus; 3) metallvardaga sondeerimine $\left({ }^{3}\right)$; autori kogemused näitavad, et süstemaatilist sondeerimist võib soovitada eeskätt liivastel ja savistel vähese kivisusega maadel; muil juhtudel, eriti väga kivistel aladel ei kujune andkihis.

* Kivisuse astme aluseks on vôetud kivide hulk 25-sentimeetrise tüsedusega mulla- 
med küllalt täpseiks; 4) looduslike ja kunstlike paljandite (ehituskaevete, siloaukude, jõeorgude jne.) kivisuse katte- ja mahuväärtuse määramine ning kirjeldamine.

Perspektiivis on võimalik peitkivide asukoha määramist teostada geofüüsikaliste meetodite abil. Vastavaid katseid on tehtud Eesti NSV Teaduste Akadeemia Geoloogia Instituudi poolt.

Sõltuvalt tööde mahust ja ülesannetest võib andmete kogumiseks kasutada kolme liiki vaatlusi: marsruut-, rekognoos- ja detailvaatlusi.

Marsruutvaatlused koos rekognoosvaatlustega annavad põhilise välitööde materjali kivisuse kaardi koostamiseks. Marsruutvaatlustel hinnatakse pinnakivisuse aste silma järgi iga kilomeetri jooksul $1-3$ korda, märgi-

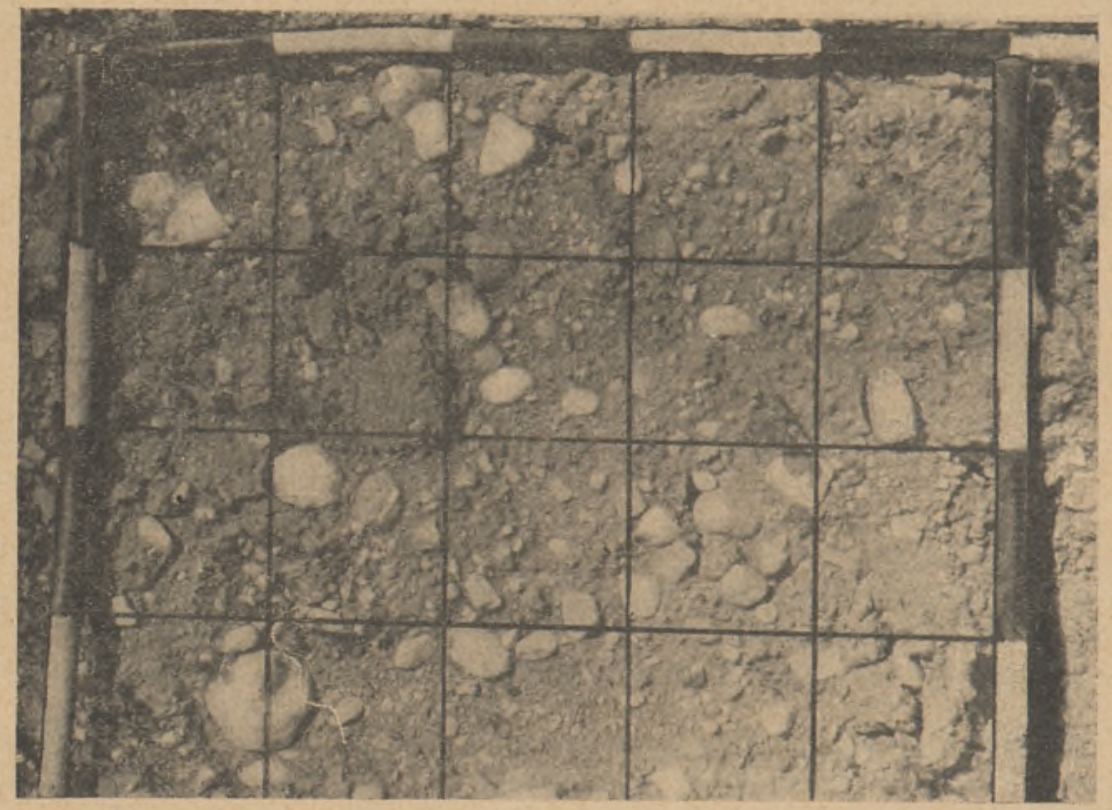

Joon. 1. Veerise katteväärtuse määramine fotomeetodil. Pindala $0,4 \times 0,5 \mathrm{~m}$, veerise katteväärtus $15 \%$. Keskmiselt erodeeritud muld. Otepää rajoon.

Foto V. Lepasepp.

takse üles kivikogumikud ja nende kubatuur, määratakse iga $5-10 \mathrm{~km}$ järel pinnakivisus $10 \times 100 \mathrm{~m}$ suurusel lapil ja kogutakse suusõnalisi andmeid kivisuse kohta masina-traktorijaamade, sovhooside ja kolhooside agronoomidelt, traktoristidelt ning brigadiridelt. Andmete kiireks ülesmärkimiseks kasutatakse vastavaid tingmärke (vt. joon. 2). Koostöös masinaIraktorijaama peaagronoomiga koostatakse masina-traktorijaama tööpiirkonna maa-alade kivisuse esialgne kartogramm, kus iga kolhoosi territooriumi või selle osa kivisust hinnatakse viiepallilise skaala järgi.

Rekognoosvaatlusi teostatakse sõltuvalt kivisuse iseloomust varieeruva vaatluspunktide tihedusega. Keskmiselt võetakse iga 1000 ha kohta üks põhi- või abipunkt. Kivisuse uurimise põhipunktis loendatakse mõõtlapilt pinnakivid, tehakse kaeve, võimaluse korral määratakse kündi takistav kivisus, määratakse kivikogumike arv ja maht, kirjeldatakse geomorfoloogilisi. mullastikulisi jt. tegureid ning teostatakse marsruutkäike vaatluspunkti ümbrusse. Eri vaatlused asetsevad siinjuures üksteise suhtes kontsentriliselt (vt. joon. 3). Sellist vaatluste süsteemi võiks nimetada diferentseeritud kontsentrite meetodiks. 
Kivisuse uurimise abipunktis tehakse väike kaeve ning loendatakse pinnakivid $10 \times 100 \mathrm{~m}$ lapil ja marsruudikorras (määratakse kivide arv ja keskmine diameeter).

Detailne uurimine peab andma alused marsruut- ja rekognoosvaatluste materjalide üldistamiseks ja kivide koristamise õigeks suunamiseks.

Detailvaatlusi teostatakse vabariigi erinevates füüsilis-geograafilistes rajoonides, üksikutes kolhoosides, kus on olemas suuremõõdulised mullastikukaardid, või paralleelselt mullastiku kaardistamisega. * Keskmiselt võetakse iga 500 ha kohta üks vaatluste põhipunkt, millele kaasub tihedam marsruutvaatlus. Uurimistulemuste põhjal koostatakse kolhoosi muldade kivisuse kartogramm (või mullastiku kaart, millele kantakse andmed kivi-

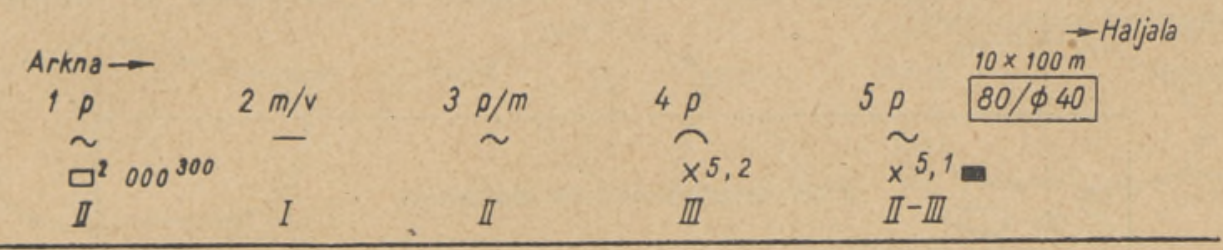

\section{TINGMÄRGID:}

$\begin{array}{ll}1,2,3 \text { jne } & - \text { kaugus lähtepunktist } k m \\ \rho & -p o ̈ l d \\ m & - \text { mets } \\ n & - \text { niit } \\ v & - \text { vósa } \\ k & - \text { karjamaa } \\ s & - \text { soo } \\ \sim & - \text { körgendik } \\ - & - \text { kallak } \\ \sim & - \text { tasand } \\ \sim & - \text { lainjas reljeef } \\ \cup & - \text { org } \\ \cup & - \text { noggu } \\ \sim & - \text { geoloogiline paljand }\end{array}$

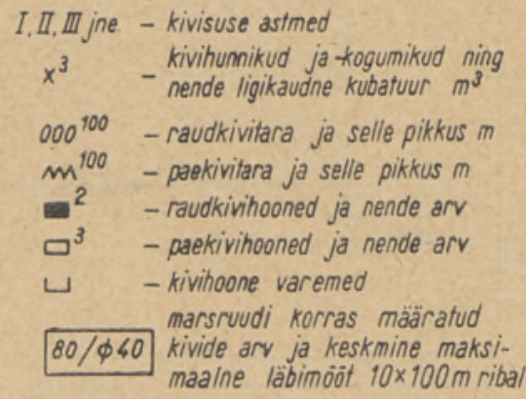

Joon. 2. Kivisuse märkimine marsruutuurimisel.

suse kohta) ja üldine kivisuse kirjeldus, määratakse kindlaks kivide varud kolhoosi territooriumil ja kivikoristustööde soovitav järjekord põldude järgi.

Kõik rekognoos- ja detailvaatluste põhipunktid seotakse omavahel marsruutvaatlustega, mida teostatakse nii jalgsi kui ka sōidukitelt.

See kombineeritud uurimismeetod annab suhteliselt lühikese ajaga üldise ülevaate kivisusest, kusjuures kasutatakse ära erinevate vaatlusliikide eelised, mis võimaldab kiiremini abistada praktikat. See meetod võiks leida kasutamist ka mõnede teiste analoogse iseloomuga uurimiste juures.

Kivisuse uurimise kohta mullastiku suuremõõdulisel kaardistamisel on teha järgmised ettepanekud.

1) Iga kontuuri kohta (mis eraldatakse kaardil) märkida kivisuse aste ja selle varieerumine (näiteks kivisuse astmetega I-III). Selleks võtta iga mullakaeve juures proovilapp $(5 \times 100 \mathrm{~m})$, kus määrata pinnakivisus marsruutmeetodil; igas puurimiskohas aga hinnata silmaga kivisuse astet.

2) Eraldada mullastiku kaardil kontuuri või tingmärkidega suure ja

* Eesti NSV-s on kivisust seni detailselt uuritud neljas kolhoosis. 
väga suure kivisusega alad. Samuti märkida kaardile suured kivikogumikud (kivivared, -tarad jne.).

3) Mulla sügav- ja abikaevete juures silmaga hinnata peidetud kivide hulk künnikihis kolmepallilise skaala järgi (nõrgalt, keskmiselt ja tugevalt kivine muld).

3. Kameraaltööd. Kameraaltöödest on olulisemad provisoorse uurimismetoodika väljatöötamine, spetsiaalse varustuse (kuupdetsimeeter, mõōtkast, sõelad, rest, võrguga raam, meetripuud, metallist sondvardad) muretsemine, väliuurimise andmete põhjal võrdlevate koondtabelite koostamine ja analüüs, kivisuse kartogrammide ja kivisuse ülevaatekaartide koostamine. Kivisuse kaardil tuleb eeskätt näidata kivide hulk ja nende esinemise iseloom (paepealne, rähk, veeris, "rähkmoreen, tardkivid ja mitmesugused segatüübid).

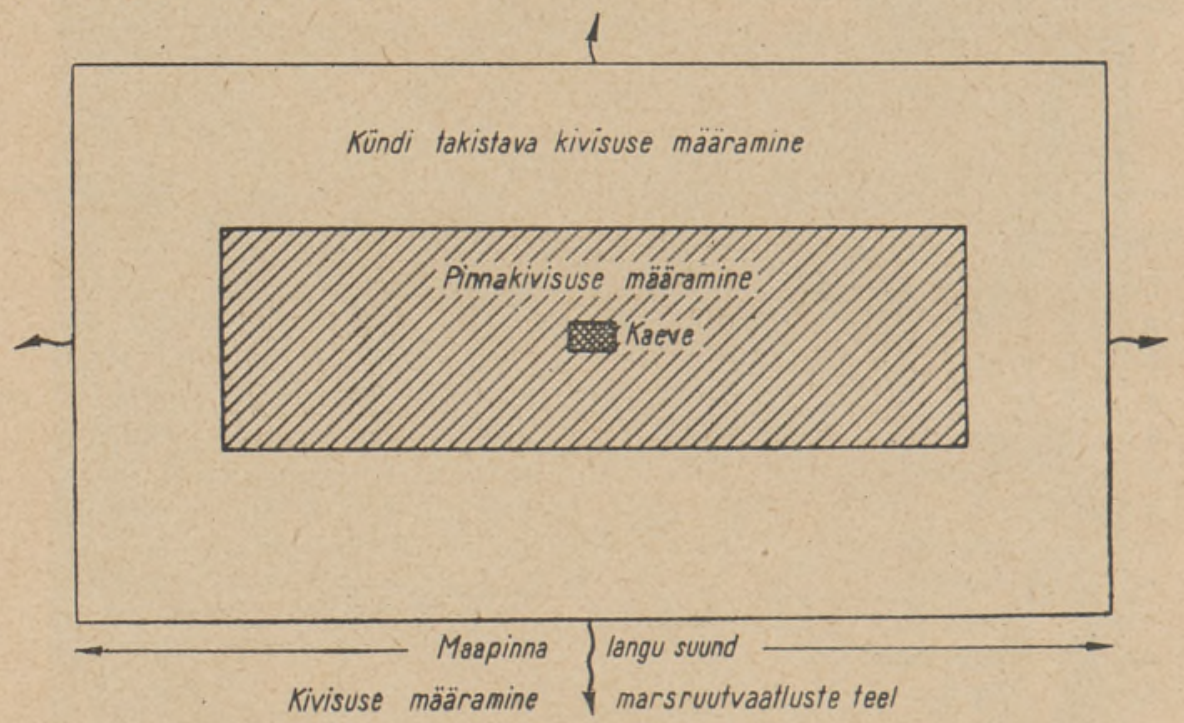

Joon. 3. Kivisuse vaatluspunkti vaatluste skeem.

\section{KIVISTE MULDADE LEVIKUST EESTI NSV-s}

Kivide paiknemist mullas ja selle pinnal võib Eesti NSV terftooriumi piires iseloomustada järgmiste seaduspärasustega.

1. Eesti NSV põhja- ja lääneosa (Madal-Eesti kõrgem osa) on tunduvalt rikkam pinnakivide poolest kui Kõrg-Eesti, mis haarab endasse peamiselt vabariigi lõunaosa ja kõrgemad alad Põhja-Eestis (Pandivere, Vooremaa, Jõhvi ja Kallaste ümbrus); kivide rohkuse erinevused künnikihis ja allpool seda on nende alade vahel aga tunduvalt väiksemad. Seda fakti ei ole seni arvestatud kivikoristustööde planeerimisel ja traktorijaamade töönormide diferentseerimisel, kus lähtuti ainult pinnakivide rohkusest.

2. Kivide leviku kohta võib märkida põhiliselt. 3 iseärasust: a) kivide levik on äärmiselt ebaühtlane (varieeruv) nii horisontaal- kui ka vertikaallõikes; b) kivide levik on sageli koldeline, mis avaldub üksikute «pesakondade», gruppide, «kivikülvide» ja «kiviväljade» esinemises; selle primaarseks põhjuseks on tõenäoliselt olnud moreeni ebaühtlane sisaldus mannerjääs ja alusreljeefi ebatasasused, mis tingisid jää sulamisperioodidel väljasulamiskollete tekkimise; c) kivide levik on tihti ribaline, mis Kõrg-Eestis on nähtavasti seoses mannerjää serva asendiga, Madal-Eestis aga peale selle ka rannamoodustistega. 
Eelmainitud, kogu vabariigi territooriumi iseloomustavate seaduspärasuste kõrval tuleb märkida ka teatud korrapärasusi kiviste muldade regionaalses esinemises. Nende esiletoomiseks on kasutatud rajoneerimise meetodit, kus üldistuse aluseks on võetud kivisuse astme ja iseloomu domineerivus (vt. joon. 5).

Eesti NSV piires võib eraldada 5 erineva kivisusega rajooni.

1. Põhja- ja Lääne-Eesti rannikul ning saartel esineb palju väga tugeva ja tugeva kivisusega alasid, kus kohati leidub rohkesti suuri rändkive ja -rahne. Laialdastel aladel esineb ka veerist (rannaklibu) ja rähka, mille mahuväärtus on $20-40 \%$. Selliseid maid on mainitud rajoonides $20-$ $-40 \%\left({ }^{8}\right)$. Erineva kivisuse iseloomuga on Põhja-Eesti järsk pankrannik (glint) ja Lääne-Eestis domineeriv lauskrannik. Ka nende rannikutüüpide

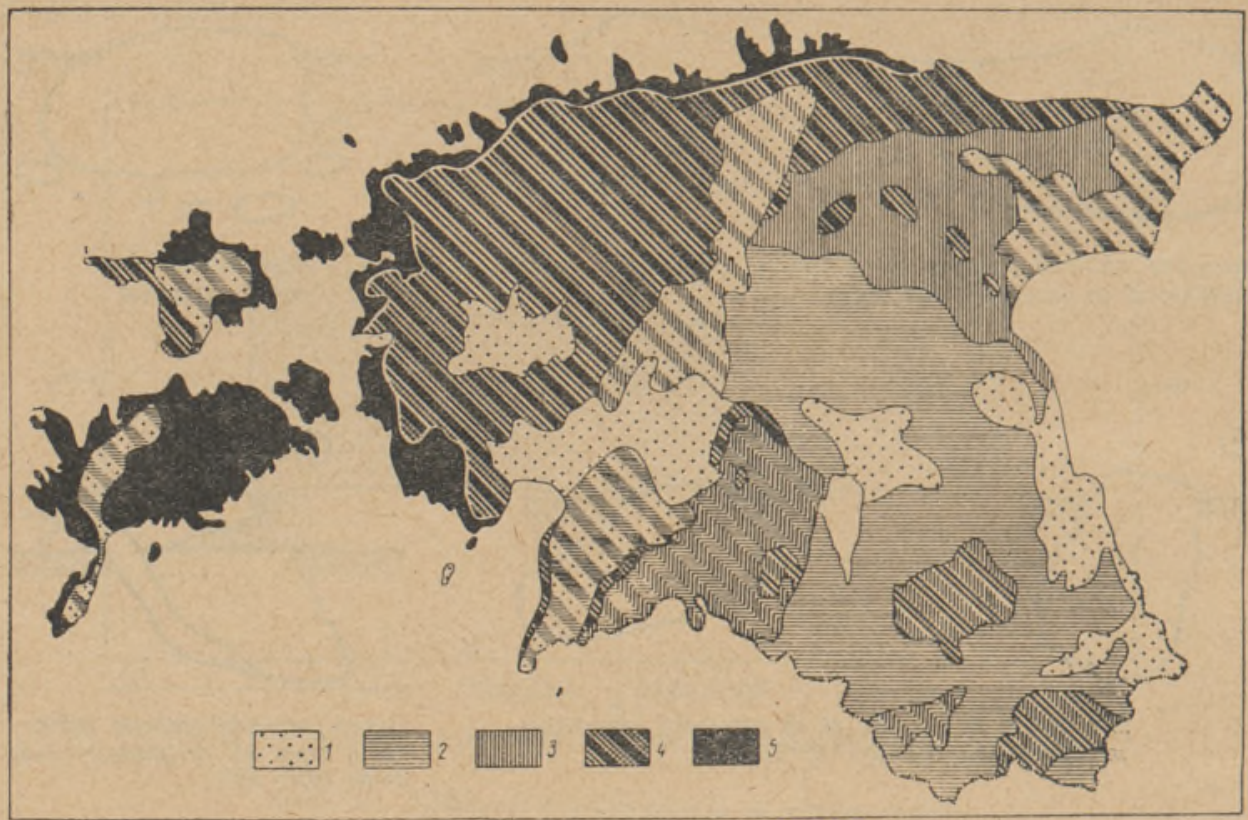

Joon. 5. Eesti NSV muldade kivisuse skemaatiline kartogramm. Kivisuse astmed: 1 - väga nōrk, 2 - nôrk, 3 - keskmine, 4 - tugev, 5 - väga tugev.

piires tulevad sisse lokaalsed erinevused sõltuvalt sellest, kas valitseb kuhjumisprotsess (kivid esinevad maetult meresetetes) vôi kulutusprotsess (kivid on välja pestud. Lauskrannikul on kõige kivisemateks piirkondadeks alad, kus põhimoreense pinnakattega kõrgemad kohad alluvad kulutusele. Olulist osa selle rajooni kivide paiknemises etendab jäätriiv, jääsurve, meresetete akumulatsioon ja abrasioon. Siin on väga palju kivivaresid ja -tarasid, näiteks Saaremaal V. Kingissepa nimelises kolhoosis katavad need 15-20\% künnimaa pindalast (joon. 6). Põllumajanduspraktika seisukohalt on nimetatud piirkonna maade kasutamine seotud raskustega, mis on tingitud mulla halbadest füüsikalistest omadustest ja masinatele kivide poolt põhjustatud kahjustustest.

2. Põhja- ja Lääne-Eesti tasandik on enamuses väga kivine, kohati aga eriti kivine. Iseloomustavaks jooneks on laialdastel aladel suur räha sisaldus mullas, mis ulatub $15-30 \%$-ni (joon. 7,8 ). 20-120-sentimeetrise diameetriga kivide arv künnikihis kõigub tavaliselt 100-1000 kivi piires ha kohta (joon. 9). Lühikese profiiliga mullad, mis paiknevad vahetult pael või kivirikkal rähkmoreenil, ei võimalda läbi viia sügavat kündi ja kahjus- 
tavad masinaid. Näiteks tuleb künnil 10 ha kohta vahetada kuni 5 adratera, ${ }^{*}$ kusjuures iga tööpäeva kohta tuleb keskmiselt 1 avarii (tööseisak) ning künniga tuuakse pinnale rohkesti kive. Külv tavalise külvikuga ei anna räha- ja veeriserikastel muldadel häid tulemusi. Põllul, kus räha katteväärtus oli $15-20 \%$, oli odrataimi 9 korda vähem kui sama põllu mittekivisel osal. Räha ja veerise sisaldus mullas suurendab ka tunduvalt veo eritakistust künnil. Tugevalt rähkseid muldi esineb selles rajoonis kuni

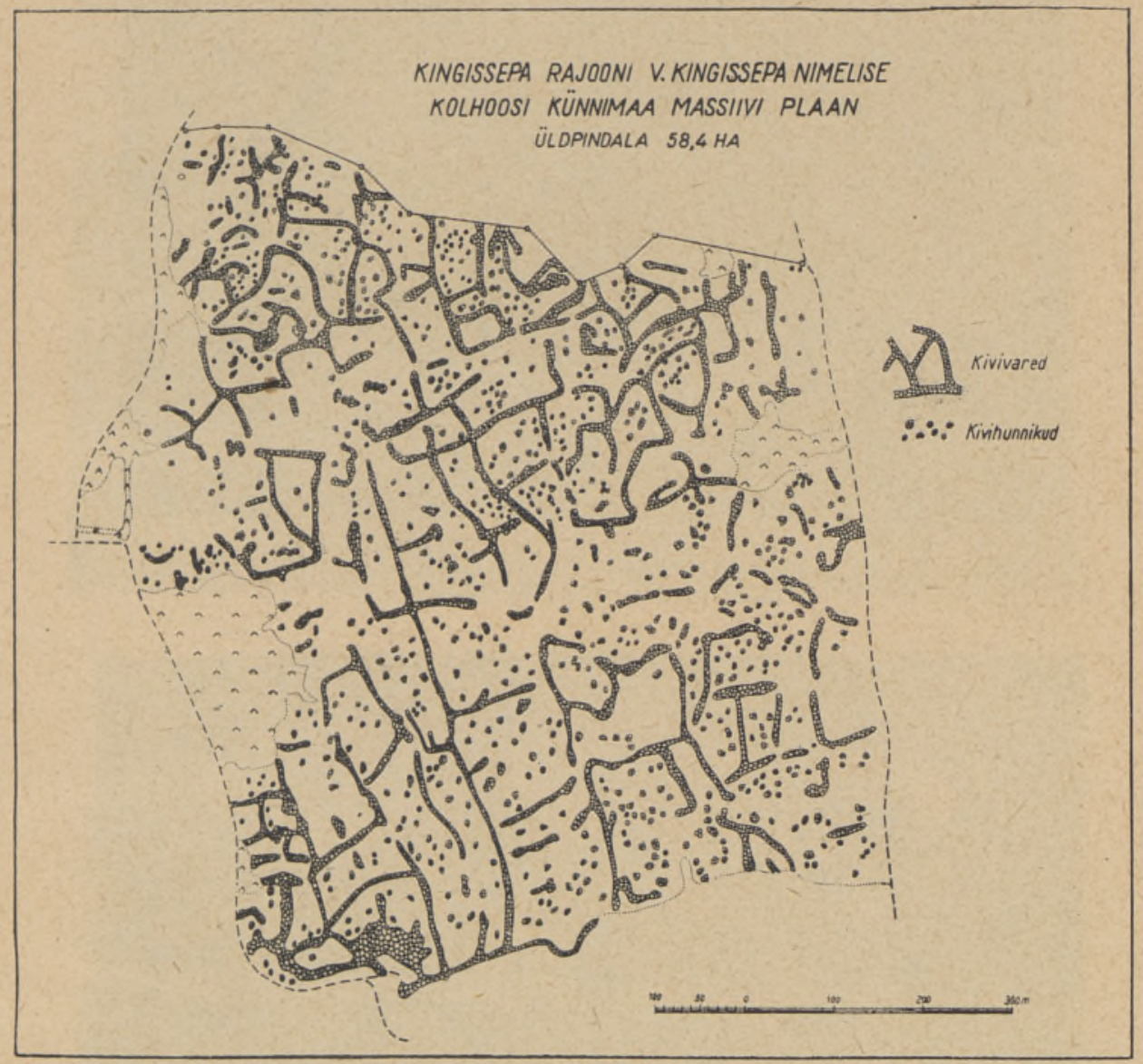

Joon. 6. Osa Kingissepa rajooni V. Kingissepa nimelise kolhoosi põllust, kus kivivared ja -tarad katavad $12-15 \%$ pōllupinnast.

$20 \%\left({ }^{6}\right)$. Rajoonis on ka rohkesti kivivaresid ja -tarasid. Harju rajooni «Kalevi» kolhoosis katavad nad koos ümbritseva harimata maaga ligikaudu $5 \%$ põllupinnast.

3. Eesti NSV moreenkõrgustikkude (Pandivere, Otepää, Haanja, Sakala) alal on kivisuse aste enamasti keskmine, kohati aga tugev. Räha ja üldse pinnakivide sisaldus mullas on võrreldes Põhja- ja Lääne-Eesti tasandiku rajooniga tunduvalt väiksem. Ole $20 \mathrm{~cm}$ suuruste rändkivide sisaldus künnikihis on aga küllaltki suur ja kõigub tavaliselt 100-300 piires ha kohta (joon. 10). Rajooni kaguosa kuplitel esineb rohkesti 5-20sentimeetrise diameetriga kive - nende arv hektaril on tavaliselt $300-3000$

* Siinjuures adratera vahetus ei tähenda, et tera oli töö ajal nōuetele vastav.

9 ENSV Tead. Akad. Toimetised 3 
ja üle selle. Veerismaterjali rohkus takistab tôsiselt külvikute ja teiste masinate tööd ning suurendab veo eritakistust.

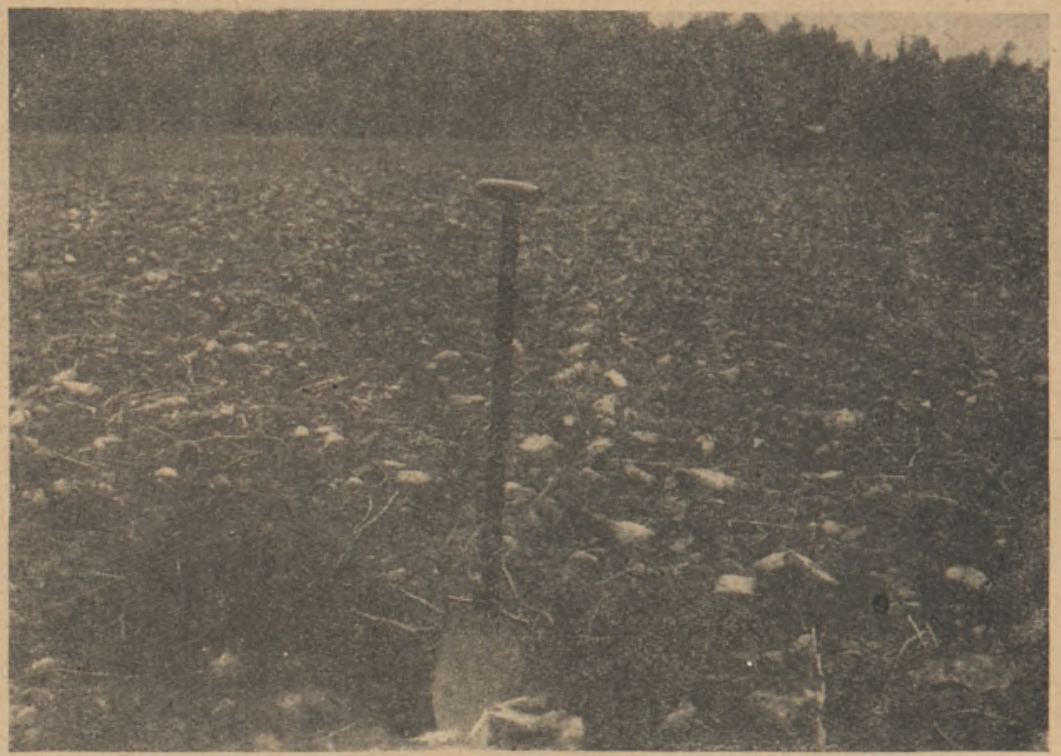

Joon. 7. Ohuke, tugevasti rähkne muld, mis sobib lutserni kasvatamiseks (Harju rajoon). Foto H. Michelson.

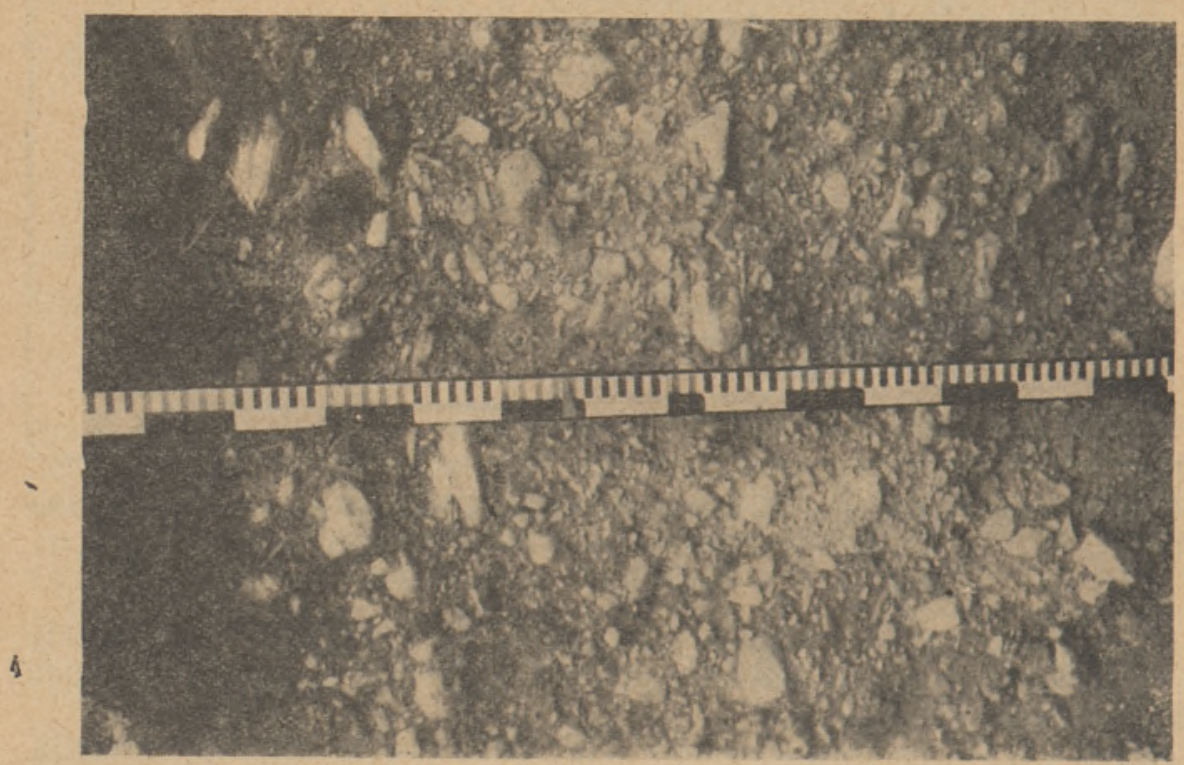

Joon. 8. Pōhja- ja Lääne-Eestile iseloomulik tugevasti kivine rähkmoreen. Räha ja veerise sisaldus moreenis mahu järgi $25 \%$. Autori foto.

Moreenkõrgustike rajoonis on kõrgemad alad kivirikkamad, s. t. mida suurem on absoluutne ja relatiivne kõrgus, seda suurem on ala kivisus (näiteks Rõuge-Haanja ümbrus, Pandivere, Sakala ja Otepää kõrgemate tippude ümbrus). Ka pinnamoe liigestatus ja erodeeritus, mis sageli kaasnevad suuremate kõrgustega, suurendavad oluliselt kivisuse astet. Kesk- 
miselt erodeeritud põllul Otepää rajooni Vorošilovi-nimelises kolhoosis ulatus veerise katteväärtus kuni $20 \%$-ni (mahuväärtus $40 \%$-ni), mis on keskmiselt 5 korda suurem kui nõrgalt erodeeritud mullal. Saagid kivirikastelt erodeeritud muldadelt on üldiselt madalad.

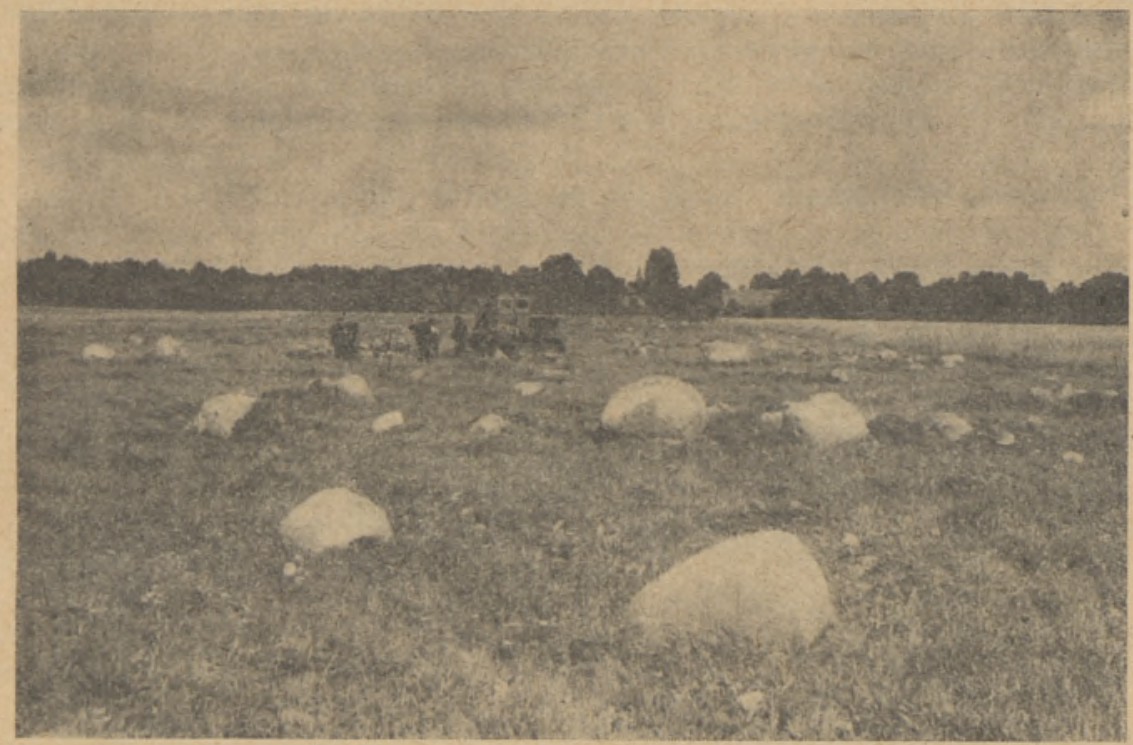

Joon. 9. Pōld Pōhja-Eestis Loksa rajoonis, kus I ha kohta tuleb keskmiselt 240 üle 40 -sentimeetrise diameetriga kivi. Kivikoristamine otstarbekas. Autori foto.

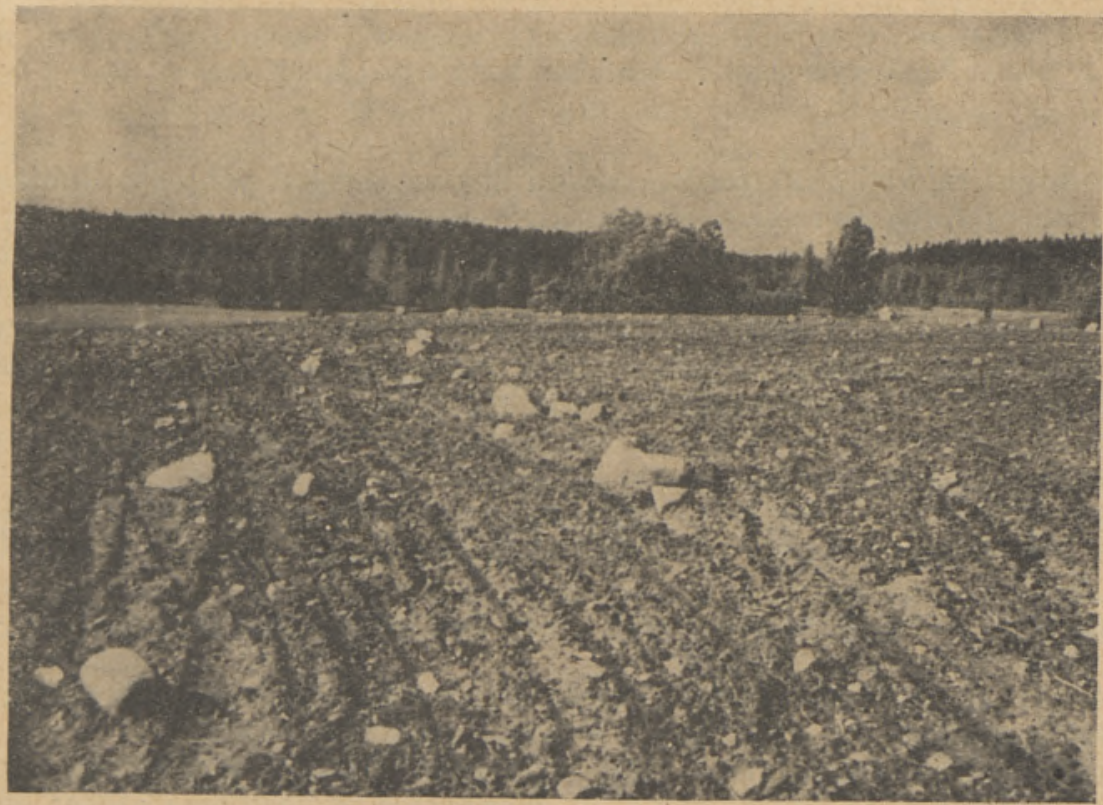

Joon. 10. Otepää kõrgustiku idaosá iseloomustav kivine pōld (Pōlva rajoon). Kivikoristamine hädavajalik. Autori foto. 
4. Kesk- ja Lõuna-Eesti lainjad tasandikud on peamiselt keskmise või nõrga kivisuse astmega. Kündi takistavaid kive on enamasti alla $200 \mathrm{I}$ ha kohta (joon. 11).

Kesk-Eestis on üheks kivirikkamaks piirkonnaks nn. Vahe-Eesti (Kõrvemaa), kus väiksemad tugevasti ja keskmiselt kivised alad (oosid, voored, põhimoreense pinnakattega alad) vahelduvad väga nõrgalt kiviste aladega (soostunud maade, soode ja liivaaladega).

Vooremaa (suurvoorte ala) ja teised voorestikud on üldiselt nōrgalt kivised, eriti lõunapoolses osas; kivirikkamateks kohtadeks on siin voorte järsud nõlvad.

Olejäänud, tasasema reljeefiga alad on nõrgalt kivised.

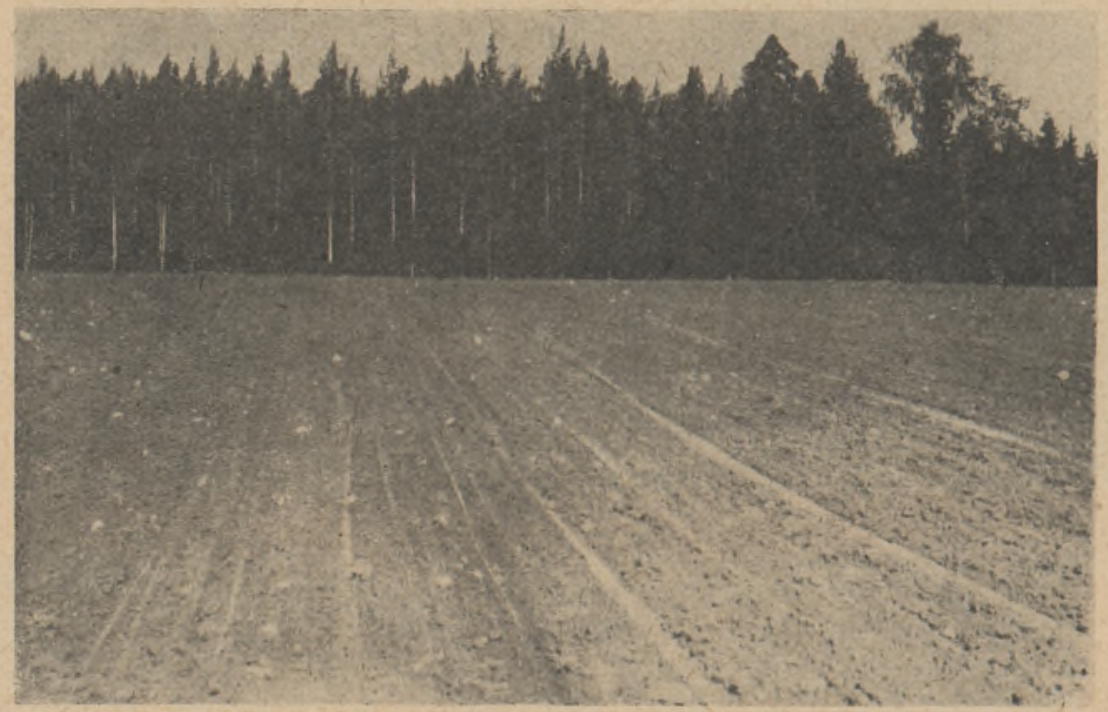

Joon. 11. Nõrgalt kivine põld lainjal tasandikul (Pōlva rajoon). Kivikoristamine teisejärgulise tähtsusega. Autori foto.

Mainitud rajooni lõunapoolne osa on kivivaesem kui põhjaosa, lubjakive leidub harva ning pinnakive on tunduvalt vähem.

5. Peipsi ja Võrtsjärve nõod ning Pärnu ja Vigala settetasandikud on nõrga ja väga nõrga kivisuse astmega. Kivised piirkonnad esinevad üksikute saartena liiva- ja savisetete ning soomassiivide foonil. Piirkonna väiksem kivisus on tingitud sellest, et need alad on olnud sorteeritud materjali (liiv, viirsavi) settebasseinideks, kuhjealadeks.

Peale nimetatud piirkondade kuuluvad siia ka väiksemad soostunud settealad Edela-Eestis, Saaremaal ja Hiiumaal.

Kui Peipsi ja Võrtsjärve nõgudes domineerivad peamiselt liivsetted, milles kohati leidub ka kive, siis Pärnu ja Vigala savisetete piirkonnad on praktiliselt kivivabad.

Seaduspäraseks nähtuseks on ka siin see, et rajooni põhjapoolne osa on kivirikkam kui lõunapoolne.

Selleks, et välitöödel kogutud uurimismaterjali oleks võimalik üldistada laiematele aladele, on tarvis tunda kivisuse geneesi.

Teguritest ja protsessidest, mis. määravad kivisuse geneesi ja leviku, on olulisemateks: 1) murenemine, 2) mannerjää esinemisega seoses olnud protsessid, 3) mere tegevus, 4) järve tegevus, 5) vooluvete tegevus (jõgede ja pinnavete tegevus), 6) põhjavete tegevus (karstinähtused), 
7) mulla külmumine ja sulamine, 8) mulla arenguprotsessid, 9) inimeste tegevus.

Neist protsessidest omavad käesoleval ajal suuremat praktilist tähtsust inimeste tegevus (eriti kivide koristamine ja traktorikünd), mulla külmumine ja sulamine ning kiirendatud erosioon. Näiteks kivide üleskündmise ja külmakerke tõttu (künnikihist ja selle alt) tuli Kostivere sovhoosis korrata kivikoristamist põldudel, mis olid eelmisel aastal kividest puhastatud. Sealjuures koristati eelmisel aastal (1953) keskmiselt $25 \mathrm{~m}^{3}$ kive hektarilt, järgmisel aastal (1954) aga veel täiendavalt $9 \mathrm{~m}^{3}$ ha kohta (s. o. $35 \%$ eelmisel aastal koristatud kogusest). Kivide üleskerkimine on tingitud kevadisest külmade ja sulade vaheldumisest olukorras, kus maapinna ülemine osa on sulanud, alumine aga külmunud. Seda protsessi soodustavad peene materjali suur osatähtsus *, kõrge põhjaveeseis, rohukamara puudumine, pealmise sula pinnase plastilisus ja paekivi lähedus. Kivide üleskerkimine ja väljakündmine on üheks oluliseks põhjuseks, mis ei võimalda korraga põldu lõplikult kividest puhastada; seda tuleb arvestada kivikoristustööde planeerimisel.

\section{KOKKUVOTE}

Edukamaks võitluseks kivisusest tingitud kahjulike nähtuste vastu põllumajanduses on vaja:

1) kiirendada kivisuse uurimise ühtse metoodika väljatöötamist ja laiendada mulla kivisuse uurimisi kivikoristustööde ratsionaalse organiseerimise ning põllumajandusmasinate ja -riistade õige valiku eesmärgil;

2) luua kivikoristustöödele kindlad organisatsioonilised alused (töönormide ja tööde mahu õige arvestus, tööde kvaliteedi parandamine ja kontroll, tööjõudluse tõstmise võimaluste ärakasutamine, tööde omahinna alandamine jt.); töötada välja efektiivsem kivikoristustööde tehnoloogia kompleksse mehhaniseerimise alusel, et viia miinimumini inimtööjõu kașutamine;

3) silmas pidades kivikoristustööde suurt mahtu ja nende tööde läbiviimiseks vajaliku aja pikkust, välja töötada spetsiaalsed masinate ja riistade konstruktsioonid töötamiseks kivistel muldadel, olemasolevate masinate juures aga võtta kasutamisele kivikahjustusi vältivad kaitseseadmed;

4) kivikoristamisel arvestada kivi kui maavara täpse arvelevõtmise vajadust; kivikoristustööd seostada ehitus- ja maaparandustöödega;

5) eriti kivistel muldadel korrigeerida agrotehnikat ja maakorraldust nende maade ratsionaalsema kasutamise eesmärgil. Näiteks õhukeste huumusevaeste, tugevasti kiviste (rähksete ja veeriseliste) muldade jaoks tuleb välja töötada meetodid ja abinõud nende kasutamiseks (kultiveerida pealtparandamise teel rohumaadeks, kasutada lutserni kasvatamiseks, metsastada, muuta aedadeks, parkideks või looduskaitsealadeks; külvil kasutada agregaate, mis kindlustavad seemnete mulda viimise, - sahkseemendaja, ketiga varustatud seemendaja, äke).

Kivikoristustööd on üheks tähtsamaks maaparandusabinõuks nii künnija rohumaadel kui ka uudis- ja jäätmaadel.

Nõukogude kord ja sotsialistliku põllumajanduse süsteem on loonud kōik tingimused selleks, et kiiresti läbi viia kivikoristustööd ja tõsta saake laialdastel aladel mittemustmulla vööndi loodeosas, sealhulgas ka Eesti NSV-s.

Eesti NSV Teaduste Akadeemia Taimekasvatuse Instituut
Saabus toimetusse

28. VI 1955.

* $0,1-0,06$ millimeetrise diameetriga csakeste sisaldus peab olema vähemalt $25-35 \%\left({ }^{5}\right)$. 
1. К. П. Богатырев, Фрагментарные (грубоскелетные) почвы и предпочвенная стадия выветривания, «Вопросы географии» (сборник), № 33, М., 1953.

2. Об улучшении сельскохозяйственного использования земель нечерноземной полосы европейской части СССР, Изд. Академии наук СССР, М., 1952.

3. Л.Т. Р а м е н с к й, К методике изучения растительности и населяемой ею среды, Ботанич. журнал, т. 37, №2 2, 1952.

4. Е. М. С е р ге е в, Общее грунтоведение, М., 1952.

5. Справочник путешественника и краеведа, под редакцией С. В. Обручева, том II, главы XII, XIV, XV, XVII, Географгиз, M., 1950.

6. K. Kild ema, Rohkem tähelepanu kivide koristamisele, «Sotsialistlik Pōllumajandus» nr. $3,1954$.

7. V. Kosar, Kultuurkarjamaade rajamis- ja hooldamistööde mehhaniseerimisest, Kogumik «Kultuurkarjamaade rajamine ja kasutamine», Tallinn, 1955.

8. A. L i ll e m a, Eesti NSV mullastiku kaart. Tallinn, 1954.

\section{О МЕТОДИКЕ И РЕЗУЛЬТАТАХ ИЗУЧЕНИЯ КАМЕНИСТОСТИ ПОЧВ ЭСТОНСКОЙ ССР}

\section{К. Т. КИЛЬДЕМА}

Резкме

Одним из важнейших мелиоративных мероприятий, имеющих большое значение для повышения урожаев сельскохозяйственных культур и расширения возможности механизаџии полевых работ в северо-западной части нечерноземной полосы, является уборка камней (валунов). До проведения камнеуборочных работ требуется соответствующий подбор и приспособление сельскохозяйственных машин и орудий.

На территории Әстонской ССР, по предварительным данным, общее количество камней на поверхности и в пахотном горизонте сельскохозяйственных угодий составляет около 30 миллионов кубометров. В очистке от камней нуждается $60 \%$ общей площади сельскохозяйственных земель республики, где содержание в пахотном слое валунов с диаметром от 20 до 120 см колеблется обычно в пределах 50-1000 единиц на гектар.

В Әстонской ССР вследствие засоренности камнями почв портятся тракторы и большая часть сельскохозяйственных машин и орудий. По этой же причине при вспашке расход чистого рабочего времени увеличивается (до $40 \%$ ), а на ремонт расходуется во время полевых работ 30-50\% всего времени. В МТС примерно одна треть сверхнормативных ремонтных расходов уходит на ликвидацию аварийных поломок, вызванных завалуненностью.

$\mathrm{K}$ задачам изучения каменистости почв относятся: а) разработка методов определения количества и объема камней в соответствии с требованиями практики сельского хозяйства; б) выяснение характера, региональных различий и закономерности в распространении каменистых почв; в) составление обзорной карты каменистости почв, которая позволяет планировать камнеуборочные работы в отдельных районах, дифференцировать нормы выработки в МТС и совхозах, учитывая каменистость, а также, правильно районировать сельскохозяйственные машины, выявлять сильно каменистые районы, где нужно внести изменения в агротехнике и землеустройстве для более рационального использования земель.

Основные принципы методики изучения каменистости: а) комплексность изучения со всесторонним учетом естественно-исторических условий и агропроизводственных особенностей районов; б) комбинированное применение маршрутного, рекогносцировочного и детального методов 
исследования в зависимости от физико-географических и производственных условий.

Институтом растениеводства Академии наук ЭССР разработана предварительная методика определения размеров и кубатуры камней, основные положения которой заключаются в следующем: а) за исходный показатель для определения размера камней берется их максимальный диаметр; б) для определения кубатуры валунов (максимальный диаметр которых находится в пределах от 20 до 300 см) составлена специальная таблица. Экспериментальная проверка таблицы показала, что отклонение рассчитанных по таблице объемов от фактических не превышало $8 \%$. Таблицей уже пользуются многие MTC и совхозы республики. Подобную таблицу можно разработать и для угловатых известняковых камней; в) кубатура куч и штабелей камня определяется по формулам объема геометрических тел, к которым больше всего подходит форма кучи или штабеля; из полученной кубатуры вычитывается объем скважности $(30-50 \%)$; г) для определения количества гальки и щебня в почве установлено 5 способов расчета -2 способа по степени покрытия галькой и щебнем поверхности почвы, 3 способа расчетов по объему; д) намечена классификация камней по их размерам и форме.

Основными элементами изучения каменистости с точки зрения проведения полевых работ являются: a) изучение лежащих на поверхности камней, с регистрацией скоплений камней; б) изучение камней в. пахотном и подпахотном слое.

Определение поверхностного камня проводится при помощи пробных плошадок, в маршрутном порядке и на глаз по пятибальной системе.

Изучение камня в пахотном и подпахотном слое можно проводить при помощи раскопок и «прикопок»; путем наблюдения за работой плугов во время вспашки; зондированием; обследованием обнажений карьеров, канав, траншей, речных русел, оврагов и т. д. В перспективе возможно изучение скрытых камней геофизическими методами. Соответствующие опыты, проведенные в Әстонии, дали удовлетворительные результаты.

В зависимости от объема и задач исследований можно выделить три категории разведывательных работ: маршрутную, рекогносцировочную и детальную разведки.

Маршрутная разведка вместе с рекогносцировкой дает основной материал для составления карты каменистости. Детальная разведка должна дать основы для обобщения других материалов и для правильного направления камнеуборочных работ.

Для исследования каменистости с целью отражения ее на крупномасштабных почвенных картах пока даны предварительные предложения.

В пределах всей территории Эстонии наблюдаются следующие закономерности в распределении камней в почве и на ее поверхности.

На севере и на западе республики, в пределах так называемой подводной части Эстонии (была в прошлые геологические эпохи покрыта водой), поверхностных валунов больше, чем в так называемой надводной части Эстонии, включающей в себя юг республики и отдельные возвышенности (Пандивере и др.) на севере.

Средняя величина камней уменьшается с севера на юг, а степень окатанности, напротив, увеличивается.

В зависимости от рельефа более каменистыми являются возвышенности и крутые склоны холмов, древние и современные морские берега, в то время как понижения менее завалунены. Большей каменистостью отличаются почвы на основной морене. Напротив, наносные сортированные, песчаные, глинистые и забьлоченные почвы - малокаменисты. 
На основании региональных различий в распространении и характере каменистости почв территория Әстонской ССР подразделена на пять районов.

Из факторов, определяющих генезис и распространение каменистых почв, существенное значение имеют: выветривание, процессы, происходившие в периоды оледенения, деятельность моря, озер, проточных вод, поверхностных вод, грунтовых вод (карстовые явления), замерзание и оттаивание почв, почвенные процессы (дерновый процесс, заболачивание и др.), деятельность человека.

Для уменьшения ущерба, причиняемого сельскому хозяйству каменистостью, необходимо: а) ускорить разработку единой методики и расширить исследования каменистости почв в целях рациональной постановки камнеуборочных работ и целесообразного подбора сельскохозяйственных машин и орудий; б) создать прочные организационные основы и разработать более эффективную технологию камнеуборочных работ на основе их комплексной механизации с целью максимального сокращения затрат людского труда и энергии; в) ввиду большого объема камнеуборочных работ и длительности срока их проведения разработать специальные конструкции машин и орудий для работы на каменистых почвах, а также различные камнезащитные приспособления к существующим маркам машин; г) в районах с сильно каменистыми почвами внести соответствующие коррективы в систему агротехнических мероприятий в целях более эффективного использования сельскохозяйственных угодий.

Институт растениеводства Академии наук Эстонской ССР
Поступила в редакцию 28 VI 1955 